\title{
Local Governments in Nigeria: Relevance and Effectiveness in Poverty Reduction and Economic Development
}

\author{
Ito Diejomaoh (Corresponding author) \\ African Institute for Applied Economics \\ 27 Nza Street, Independence Layout, Enugu \\ Tel: +2348059273107 E-mail: itobore@gmail.com \\ Prof. Eric Eboh \\ African Institute for Applied Economics \\ 27 Nza Street, Independence Layout, Enugu \\ Tel: +2348036660475 E-mail: eceboh@yahoo.com
}

\begin{abstract}
This paper examines the local government system in Nigeria, its relevance and impact in poverty reduction, economic growth and sustainable development. After a review of the local government system in Nigeria as an example of political, fiscal and economic decentralization, it examines the nature and evolution of local government in Nigeria as well as the roles and responsibilities of the local governments in the Nigerian context. In examining the deficiencies of the local government system in Nigeria one of the major issues seem to be a problem of accountability of local governments along with serious capacity issues. The paper concludes with a treatment of the imperatives for optimising the effectiveness of local governments in Nigeria.
\end{abstract}

Keywords: Local Government, Effectiveness, Poverty Alleviation

\section{Local Governments as a Example of Decentralisation}

Decentralisation refers to a process by which a central government formally cedes powers to actors/institutions at lower levels in a political-administrative and territorial hierarchy (Mawhood 1983; Smith 1985). It is a politicoadministrative arrangement which entails the devolution of authority to plan, make decisions and manage public functions from the central government to subordinate organisation, agencies or units of government, either geographically or structurally (Anyanwu, 1999). Decentralisation of social and development functions responsibilities is a vital feature of political and economic reforms in many countries. The extent and nature of decentralisation however, differs from one country to another, depending on constitutional and political contexts.

In unitary states where power, roles and functions are merely administratively delegated, the lower authorities tend to act as mere agents, conduits or surrogates of the central national government. This is a weak form of decentralisation because downward accountability to local communities is de-emphasized in favour of upward accountability to the central authorities. But, in federal or quasi-federal settings, the sub-national including the local governments have varying degrees of autonomy to the extent defined by the National Constitution. In federal settings, significant fiscal functions (revenue generation and expenditure functions) are shared between the central and lower levels of government. Some examples include United States, Australia, Canada, Brazil, Switzerland, Germany, Nigeria and India.

Decentralisation is theoretically justified on both political and economic grounds. Economic-side arguments emphasize the advantages in terms of promoting inclusive and broad-based growth, optimal use of local and national resources for economic development. The proposition is that achieving economic efficiency and welfare maximisation requires an optimal balance of fiscal and policy jurisdictions between central and local authorities. The theories emphasize that different layers of government have different comparative advantages (in terms of capacity, efficiency and effectiveness) for providing different kinds and levels of public goods. It is argued that the State can best maximise social welfare through decentralisation such that locally-consumed public goods (that is, public goods 
not national in character) should be provided by respective local authorities. Where the consumption of a public good is confined to spatial or geographical scope, there is economic merit for lower governments to take responsibility. The central economic postulate of fiscal and policy decentralisation is that the provision of public services should be located at the lowest level of government consistent with the incidence of costs and benefits, since lower tiers of governments have greater information about local conditions and can therefore, provide services that are better suited to the needs and preferences of the local population. But, such responsibility and functions would need to be matched with fiscal powers and resource control.

On the political side, decentralisation is a theoretically valid tool for managing in-country heterogeneities, reduce power-sharing tensions and cater for divergent needs of the different nationalities/societies within a country. It is reasoned that decentralisation could reduce ethnic conflict and secessionism by giving groups control over their own political, social and economic affairs (Miodownik and Eidelson, 2004). But, there are risks also. Decentralisation may aggravate conflicts by intensifying opportunities for canvassing regional/ethnic identities, enacting discriminatory regional legislations and emboldening regional or local groups with resources to intensify ethnic conflicts and secessionism (Brancati, 2005). If revenue decentralisation is not congruent with the decentralisation of responsibilities and functions, there is vertical fiscal imbalance (Herber 1979; Anyanwu, 1999) and local authorities may lack the fiscal capacity to provide critical local public services.

\section{Nature and Evolution of Local Government System in Nigeria}

The local government has been defined as "government by the popularly elected bodies charged with administrative and executive duties in matters concerning the inhabitants of a particular district or place" (Appadorai, 1975:287). Conceptually, and on a political level, the local government involves participation in the governing process at the grassroots level. This implies legal and administrative decentralisation of authority, power and personnel by a higher level of government to a community with a will of its own, performing specific functions as within the wider national framework. On an administrative level, the local government is a government at the grassroots level of administration. Due to its closeness to the people, it has as its aim the meeting of specific grassroots needs of the people.

In Nigeria, the local government system operates within the "presidential model". The Chairman of the LGA is directly elected by eligible voters in the local government area, and governs in collaboration with the legislative arm of the local government. Local council members are elected from single member wards (i.e. districts). The term of both the chairman and council of the LGAs is currently three years, but varies from state to state, depending on what has been legislated by the State House of Assembly.

Politically, Nigeria is a federation comprising three tiers of government -the federal government, 36 state governments, federal capital territory (FCT) and 774 local governments. In total, Nigeria has 812 separate political jurisdictions, synonymous with 812 different centres of policy decision-making/resource allocations. The basic principles of the sharing of roles and responsibilities are broadly enshrined in the country's supreme law Constitution of the Federal Republic of Nigeria 1999.

In pre-colonial times, the antecedent of local government was the native administration established by the colonial administration. It was meant to adapt to purposes of local government structures already present in the institutions of the various ethnic groups. The idea was for these existing structures to develop into effective tools of government ready for use (after pertinent modifications) by the colonialists. The Native Administration was charged with the collection of taxes, maintenance of law and order, road construction and maintenance, and sanitary inspection, especially in township areas.

With the advent of independence, local government became a de facto agent of administering regional projects and programmes at the local level. Under military administration and during the Gowon regime which lasted from 1967 to 1975, different states operated different systems of local government. In the Northern states, the Emirs retained some of their powers and influence because the councillors appointed by the military governors were traditionally and spiritually expected to defer to the authority of the Emir. The Eastern States and in the Midwest states abandoned the conciliar system adopted in the 1950s for development administration, modelled after the French system of "deconcentration".

The Local Governments underwent their first major reform in 1976 during the military administration of General 
Olusegun Obasanjo. These reforms formed the foundation of the present-day local government system and were an attempt to restructure the Local Government administration to a form fitting for modern society. The fundamental result of the 1976 reforms was to introduce a uniform system of local government administration throughout the country. It was based on a conviction that a strong local authority with clearly defined roles and responsibilities in a power-sharing relationship with the states is an institutional imperative. Based on the 1976 reforms, local government became recognized as a tier of government entitled to a share of national revenue consequent on its constitutionally allocated functions (Imuetinyan, 2002).

In the 1979 Constitution, the main tenets of the 1976 reform were incorporated. A central idea of the constitution was the provision that "the government of every state shall ensure their existence under a law which provides for the establishment, structure, composition, finance and functions of such councils." In this way, it subjected the relevance, strength and degree of autonomy to the decision of the respective state governments.

The reforms also introduced population criterion under which a local government could be created. Consequently, a population of within 150,000 to 800,000 was considered feasible for a local government. This was done to avoid the creation of non-viable local council and for easy accessibility. There was provision for elective positions having the chairmen as executive head of local government with supervisory councillors constituting the cabinet. Regarding finances, the local governments for the first time received significant financial inflows from the federal to guarantee that they start off on a solid resource foundation. About $\$ 100$ million was made available during the 1976/77 financial year to all the local governments in the federation.

The provisions of the 1999 constitution form the institutional framework for local government system today in Nigeria. It states "the government of every state shall, subject to the Section 8 of this constitution, ensure their existence under a law which provides for the establishment, structure, composition, finance and functions of such councils" (Federal Republic of Nigeria Constitution, 1999).

The 1999 constitution ensures that the local government consolidates the tripartite system of government (made up of executive, legislature and judiciary) at grassroots level. Executive powers are vested in the chairman, vicechairman, supervisor or supervisory councillors, as well as the structure of local government bureaucracy. The legislative functions are meant to be performed by the councillors, who represent the wards which make up the Local Government Area. The judiciary on the other hand, is streamlined with the federal and state and the local government can avail itself of the judicial process available to it.

It is important to note that the each successive creation of local governments beginning from 1976 has been done by federal military governments. In 1976, it was the Obasanjo administration, in 1991, Babangida administration, in 1996, it was Abacha administration and in 1999, it was Abubakar administration. This shows that the creation and spatial delineation of local government territories, just like state government territories, did not have advantage of democratic processes.

\section{Roles and Responsibilities of Local Governments}

The 1999 constitution outlines the main functions of the local government in Nigeria as

1. The consideration and the making of recommendations to a State commission on economic planning or any similar body on:

2. the economic development of the State, particularly in so far as the areas of authority of the council and of the State are affected, and

3. proposals made by the said commission or body;

4. Collection of rates, radio and television licences;

5. Establishment and maintenance of cemeteries, burial grounds and homes for the destitute or infirm;

6. Licensing of bicycles, trucks (other than mechanically propelled trucks), canoes, wheel barrows and carts;

7. Establishment, maintenance and regulation of slaughter houses, slaughter slabs, markets, motor parks and public conveniences;

8. Construction and maintenance of roads, streets, street lightings, drains and other public highways, parks, 
gardens, open spaces, or such public facilities as may be prescribed from time to time by the House of Assembly of a State;

9. Naming of roads and streets and numbering of houses;

10. Provision and maintenance of public conveniences, sewage and refuse disposal;

11. Registration of all births, deaths and marriages;

12. Assessment of privately owned houses or tenements for the purpose of levying such rates as may be prescribed by the House of Assembly of a State; and

13. Control and regulation of:

14. out-door advertising and hoarding,

15. movement and keeping of pets of all description,

16. shops and kiosks,

17. restaurants, bakeries and other places for sale of food to the public,

18. laundries, and

19. licensing, regulation and control of the sale of liquor.

With regard to function, a local government council shall include participation of such council in the Government of a State as respects the following matters -

1. The provision and maintenance of primary, adult and vocational education;

2. The development of agriculture and natural resources, other than the exploitation of materials

3. The provision and maintenance of health services; and

4. Such other functions as may be conferred on a local government council by the House of Assembly of the State.

\subsection{Local government, public goods and good governance}

The role of government should be limited to the production of those goods or services which people want but that, without Government intervention, individuals could not produce for themselves through voluntary means. Markets create poor incentives when it comes to the private provision of public goods. A public good is a good that is characterised by non-rivalry and non-exclusivity. In other words, a public good exists when consumption of a good by one person does not reduce the consumption of the good by another person, and when once the good is provided it is necessarily provided to all, that is, no person or entity can be excluded. Examples are sanitation, security, etc.

A local government is a system of government whereby the State allows the establishment of local units of government with powers and authority to make local decisions on matters that affect the local communities and to mobilize local resources for implementation or execution of the decisions made.

Local governments worldwide are considered as strategic institutions for the provision of basic socio-economic, environment and other services. Their strategic vantage proximity to the grassroots makes them valuable and viable for providing effective and efficient services required by the community. They can and should be engines of growth and drivers of development. They provide cultural, educational, management, research, commerce and political services. They also offer employment, health facilities and boost the local economy, and by extension, the national economy.

Public functions can be delegated, with some limitations, to any level or unit of government, but responsibility is typically assigned to the organization that has direct contact with the consumer. This ultimate responsibility for a public service does not necessarily mean that other public entities or governments have no responsibility. Actual responsibility for public functions is usually divided among public sector actors.

The objectives of local government should include:

- To establish local representative government institutions through which appropriate services and development activities can be made more responsive to the local community; 
- To provide opportunities for local communities to exercise their democratic right to self governance and determination at the local levels, and to encourage and develop initiatives and leadership potential;

- To mobilize human and material resources through the involvement of members of the public in their local development; and

- To provide a two way channel of communication between the local communities and the central government (Omamo, 1995).

Oviasuyi et al. (2010) outline some good characteristics for good governance in local government administration. These include:

(1) Participation: Participation by both men and women is central to good governance; it could be either direct or through legitimate intermediate institutions or representation. Good governance implies and requires that the processes of participation are guided by principles and standards of integrity, transparency and accountability; it is the function of local government administration to ensure that concerns of the most vulnerable in society are taken into consideration in decision making. It should be noted that the participation that will give rise to good governance is one that is devoid of manipulation through unethical and non-transparent practice.

(2) Transparency: Where there is good governance, all that is at stake is public interest and there will be nothing to hide. The handling of issues, such as service delivery, appointments to public positions need to be done in a transparent manner. It should be clear that, government presence and access to resources would remain less satisfactory to the people unless it is based on transparency.

(3) Responsiveness: It means that public policy decisions and implementation represent adequate responses to popular needs and expectations; good governance requires that the fundamental interest and ultimate purpose that defines policies and actions of government must represent adequate response to the genuine and legitimate needs of the people. Good governance requires that institutions and processes of government try to serve all stakeholders within a reasonable timeframe.

(4) Rule of Law: Rule of law as an essential feature of good governance implies the existence of fair legal frameworks that are enforced impartially, and constitutional procedural arrangements are adhered to consistently.

(5) Effectiveness and Efficiency: Good governance in Local Government administration makes possible that adequate value and benefits are derived from government resources committed to programmes and projects of government. Good governance in this regards means that processes and institutions produce results that meet the needs of society, while making the best use of available resources at their disposal.

(6) Accountability: Accountability means that people will be able to hold local government authorities responsible for public issues as it is affecting them. In order words, accountability involves an obligation to explain or justify specific actions (Heald, 1983). This is a key requirement for good governance in local government administration in general, and a system or an institution is accountable to those who will be affected by its decisions or actions. It should be noted, therefore, that accountability cannot be enforced without transparency, the rule of law and constitutionality.

\section{Structure of Local Government Finance in Nigeria}

Even though local government reforms clearly articulated the idea of a three-tiered federation in Nigeria, its consequent recognition of 'revenue sharing and administrative arrangements" has led to many problems including intergovernmental conflicts, structural organizational problems, financial problems, shortage of qualified manpower, the place of traditional authority in local government and political and bureaucratic corruption.

Specifically, Nigerian fiscal federalism structure involves the allocation of expenditure and tax-raising powers among the federal, state and local government. As the financial relationship between and among existing tiers of governments, fiscal federalism deals with the system of transfer or grants through which the federal government shares its revenue with state and local government.

In Nigeria, local government expenditure regularly exceeds the potential for revenue sources owing to a gap between their resource requirements and their fiscal capacity. This is due to the unwieldy nature of their revenue rights and fiscal jurisdiction with the duties and functions constitutionally allocated to them. It is well-known and 
has been widely commented that fiscal laws in Nigeria give more taxation power to the federal government than the lower tiers of government.

The significant sequential developments in revenue allocation formula since the return to democratic governance in 1999 can be outlined as follows (Jimoh, 2003 and Ekpo, 2004).

- In 1999, the democratic government inherited the revenue allocation formula that has been in existence since 1992 . The formula gives $48.5 \%$ to federal government, $24 \%$ to state governments and $20 \%$ to local governments and $7.5 \%$ to special funds (which was distributed as follows: FCT 1\%, Ecology $2 \%$, Stabilisation 1.5\%, and Natural Resources 3\%).

- While this formula was in use, the Revenue Mobilisation Allocation and Fiscal Commission (RMAFC) recommended to the National Assembly the formula - federal government $41.3 \%$, state governments $31 \%$, local governments $16 \%$ and special funds $11.7 \%$ (to be shared as follows - FCT $1.2 \%$, Ecology $1 \%$, Natural Resources 1\%, Agriculture and Solid Mineral Development 1.5\%, Basic Education 7\%).

- Amidst debate on the RMAFC-recommended formula, there was the Supreme Court Verdict in April 2002 on the Resources Control Suit which nullified provision of Special Funds in any given Revenue Allocation Formula.

- In May 2002, the Federal Government invoked an Executive Order to redistribute the revenue as follows federal government $56 \%$, states $24 \%$ and local governments $20 \%$.

- Following criticisms, the Federal Government in July 2002, reviewed the Executive Order as follows federal government $54.68 \%$, states $24.72 \%$ and local governments $20.60 \%$.

- In March 2004, the Federal Government issued a modification which increased states' share to $26.72 \%$ and reduced federal government's share to $52.68 \%$. This formula remains in force, until the National Assembly legislates on a new revenue allocation formula.

Table 2 shows the trend in revenue allocation to the tiers of government.

Compared to periods before return to democratic governance in 1999, states and local governments now control increased share of the federation revenue. During periods of military rule, revenue sharing was heavily distorted because of non-adherence to the constitutional imperatives of fiscal federalism. But, currently, state and local governments account for about $50 \%$ of consolidated public sector spending (NPC, 2004); and sub-national governments have become increasingly significant in the overall national fiscal profile.

\section{Potentials of Local Governments for Promoting Social and Economic Development}

Economic growth is the increase of per capita gross domestic product (GDP) or other measures of aggregate income, typically reported as the annual rate of change in real GDP. It is primarily driven by improvements in productivity, which involves producing more goods and services with the same inputs of labour, capital, energy and materials. Economic development is a concept that implies a bit more. It includes the increase in the standard of living in a nation's population with sustained growth from a simple, low-income economy to a modern, high-income economy. It implies an improvement in the local quality of life. Its scope includes the process and policies by which a nation improves the economic, political, and social well-being of its people.

Local governments have a role to play in the economic development of any nation. Constitutionally, they should provide for the democratic representation of local communities. This role covers a very wide range of responsibilities and services which impact heavily on the livelihoods of individuals. They are, for example, key to determining where infrastructure should be located, to protecting our environment, and to providing services which are crucial to our quality of life - primary schools, primary healthcare facilities, drinking water, recreational facilities, libraries, roads and other services.

In Nigeria, the Federal Government is not best placed to respond to every issue faced by local communities. For this reason, local governments need greater freedom and capacity to tackle local issues locally, working on its own initiative and in partnership with other local and State agencies. 
This role of local governments can be specified in:

\subsection{Provision of infrastructure and related services}

Infrastructure refers to basic facilities, amenities and installations which underpin the operations of firms and households depend. This definition covers the gamut of services that are essential for the conduct, growth, sustenance of social, business and economic processes of a community. Common examples include transportation, water, electricity, communication, health and education facilities and systems. Infrastructure, whether social or economic, plays a significant role in the economy. It eases productive activities by alleviating costs and hence, makes firms more competitive. No economy can grow and develop without robust and efficient infrastructure.

While some aspects of infrastructural development may lean more heavily on the Federal Government, local governments have key roles in the provision and enhancement of certain infrastructural services.

Transportation: Many roads in rural areas come under the authority of local governments. When one considers that agriculture production in Nigeria is a largely rural affair, the condition of rural roads takes on added significance. A basic problem for local agricultural producers is the high cost of transportation of these goods. A considerable part of these costs are attributable to these roads. If local governments were able to come up with innovative ways to fund and effectively implement the improvement of these roads, the ability of rural farmers to compete in a larger market would grow in due measure. Additional features like provision of streetlights (sadly lacking in many areas) are initiatives that local governments can implement.

Waste management and sanitation: According to WHO, Sanitation generally refers to the provision of facilities and services for the safe disposal of human urine and faeces. Sanitation also refers to the maintenance of hygienic conditions, through services such as garbage collection and wastewater disposal. Inadequate sanitation is a major cause of disease world-wide and improving sanitation is known to have a significant beneficial impact on health both in households and across communities. Improved health impacts directly on human capital and its productivity. Local governments have constitutional responsibilities here in both the provision of infrastructure and services.

In general terms and with regards to infrastructural development at the local government level, a measure that can and needs to be adopted by innovative local governments is to encourage private sector participation through methods such as build, operate and transfer (BOT), build, own, operate and transfer (BOOT), rehabilitate, own and transfer (ROT) and concession as well as provide counterpart funding for major infrastructure projects for which either the resource requirements are too high or the incentive too low for private sector participation.

\subsection{Healthcare provision}

According to W.H.O. Primary Health Care means essential health care based on practical, scientifically, sound and socially acceptable methods and technology, made universally accessible to individuals and families in the community through their full participation and at a cost which the country can afford to maintain at every stage of their development in the spirit of self reliance and self determination. Primary Health Care has its foundations at the local government level and forms an integral part of the Nigerian social and economic development. It is the first level contact of the individual and community in the national health system, thus bringing health care as close as possible to where people live and work and contributes the first element of a continuing health care process. The health care system begins at the local level where its widest reach can be achieved.

The primary health care system attempts to address peoples, "health needs" through an integrated approach utilizing other sectors such as agriculture, education, housing, social and medical services. The integrated approach supposed to encourage active horizontal relationships between people and their local services as opposed to the traditional vertical relationships. A health care system that is soundly rooted in a local government that is closer to the people is specially poised to be more effective, as it can intervene in the community on different levels and in different ways. Ideally, entrusting Primary Health Care to local governments should have the effect of making healthcare services more effective and closer to the grassroots.

It is worthwhile to note that the healthcare system in Nigeria is severely hampered by a shortage of well-trained medical personnel.

\subsection{Development of locally-customised poverty alleviation initiatives}


While acknowledging the central role economic growth can potentially play in human development, poverty reduction and the achievement of the Millennium Development Goals, it is becoming widely understood amongst the development community that special efforts must be made to ensure poorer sections of society are able to participate in economic growth. Consequently, poverty alleviation measures are of paramount importance.

Local governments, given their grassroots location, have a special capacity to impact on poverty in Nigeria. This is in line with the efficient services or efficiency theory of local government. The efficient services theorists believe that the local government occupies the best position for the efficient performances of certain functions. This is made possible because of the nearness of the council of the people, and the manageability of the population.

A key problem hampering the effectiveness of poverty alleviation measures to date in Nigeria has been identified as a lack of targeting mechanisms for the poor and the fact that most of the programmes do not focus directly on the poor (Obadan, 2002). Local governments are specially poised to reach the poor in a more direct way. Their closeness allows them to choose measures that, instead of being general and prescriptive, address the specific needs of their community and take into account the concrete situation of these communities. It is highly advisable that each local government seek to develop tailor-made poverty alleviation programmes. They may be completely new concepts of programmes adapted from national initiatives to their own specific circumstances. Poverty alleviation measures taken at the federal level will be more effective and sustainable if complemented or reinforced by reforms at the state and local government levels.

\subsection{Education}

In Nigeria, education is administered by three branches of government: primary education is under the largely control of local governments, secondary schools fall to a great extent under the jurisdiction of the state government and higher education is administered by both the federal and state government. The issue of gaps in the institutional capacity to deliver primary education of a sound quality is crucial in the management of primary education in Nigeria. There is also the need for the creation of more social awareness on the recent UBE Bill to ensure compliance. The various local governments should also back this up with edicts and byelaws where necessary as well as formulate clear policies on enrolment of pupils, funding, provision of facilities and quality assurance.

\subsection{Business environment}

Business environment refers to the enabling conditions for private enterprise and business competitiveness in an economy. It covers a range of policy, regulatory, legal and institutional factors that determine the incentives for private sector investment. Nigeria's sub-national jurisdictions (state and local governments) are crucial in ensuring good business environment and enhancing Nigeria's global economic competitiveness ratings. Like every federation, business environment in Nigeria is the shared responsibility of the central and sub-national governments - federal, state and local. Hence, the overall business environment will depend upon complementation and synergy between these levels of government. Provision of good infrastructure and a higher quality of human capital can give local communities a competitive edge in the area of attracting investment, and the resulting employment and income from taxes, to their areas. A poor business environment implies indirect costs to a business that can deter them from situating their businesses in that community.

According to a landmark study on the sub-national business environment in Nigeria, ${ }^{1}$ Security and Business Development Support and Investment Promotion, two measures of the business environment were the biggest culprits in the worsening of Nigeria's business environment. Local governments that work in improving these two measures can significantly improve their competitive edge in attracting investments.

Security: Initiatives in community policing need to be embraced by local governments in Nigeria. Community policing entails community partnership in creating a safe and secure environment for all. It is policing whereby the people take active part in their own affairs. With community policing, the police is not seen as a stranger whose

\footnotetext{
${ }^{1}$ Business Environment and Competitiveness Across Nigerian States (BECANS), an initiative of the African Institute for Applied Economics, works with stakeholders to measure, benchmark and monitor the sub-national business environment. Monitoring and reporting the business environment is important for designing and implementing policy and institutional reforms by the federal, state and local governments.
} 
presence stands for danger and imminent hazard but as partners in development. Effective community policing has a positive impact on reducing neighbourhood crime, helping to reduce fear of crime and enhancing the quality of life in the community. Since neither the police nor the criminal justice system can bear the responsibility of ensuring a safe and secure community alone, the public (with active coordination by local governments) has a very active role to play in ensuring public safety

Regulatory services and administration of taxes, levies and fees: The institutional environment refers to the public sector framework within which government discharges its basic functions to society and economy. In particular, regulatory functions encompass public administration services, laws and law enforcement, rules, codes and procedures by which government renders services to private enterprises. To perform well, businesses require well functioning legal and enforcement systems and efficient and transparent public administration. Procedures that are bureaucratic, time consuming, costly and non-transparent lead to arbitrariness and provide room for large-scale corruption.

A key role that local governments have to play is related to the easy, transparent and efficient administration of taxes, levies and fees. Many small businesses rely on the local government for their control and regulation (shops, kiosks, restaurants, etc.). A conscious effort needs to be made by local governments to facilitate and ease their regulatory processes. Local governments have an unsavoury reputation for intolerance towards and, in some cases, harassment of small and microenterprises. They need rather to provide them with services that facilitate their work.

\section{Factors Militating Against the Effectiveness of Local Governments in Nigeria}

Despite the justification for the establishment of local government and its inevitable importance to the people at the grassroots level, this tier of government seems not to have justified the reasons for which it was established. The questions that summarily come to one's mind are: why has local government not lived up to its expectations? What are the causes of these seemingly conspicuous weaknesses? What are the challenges of the local government? And how can these weaknesses be corrected and the challenges met? The problems of local government are multifaceted and include:

\subsection{Lack of fiscal sustainability, budgeting expertise and economic mismanagement}

Despite the increase in the total amount of funds available to local government in Nigeria in recent years, its economic and financial profile is still very poor, relative to the development programme it is expected to carry out. More importantly local governments depend too heavily on sources of income beyond its control and have low internal revenue generating capacity. Local governments obtained almost $50 \%$ of their revenue from the federation account with an additional $31 \%$ coming from various grants and funds. They only generated $2.5 \%$ internally (see table 4). The local governments also suffer from a lack of sufficient technical expertise and ignorance of the budgeting process. More importantly, economic decisions seem to lack the input of evidence. Furthermore, local governments depend to a large extent of funds outside their control. The release of these funds, (especially the grants), are often erratic and irregular, seriously hampering proper planning.

\subsection{Low technical and managerial capacities and skills}

In 1992, as a decentralisation reform, all employees under the former "local government service commission" were reassigned under political officers in the local governments. Though nominally retaining their conditions of remuneration, their actual pay packages and conditions of service were largely at the disposal of the local government authorities.

With a few notable exceptions, local governments have largely experienced and still experience a shortfall of skilled, technical and professional staff across various sectors (health, works and maintenance, infrastructural development). They often lack even basic managerial capacity. A good part of this problem can be attributable to the low profile local government councils have in the radar of good professionals. Often they can only afford to attract mediocre staff. The recruitment process of some local governments in Nigeria has also been called to question with claims of it being influenced by favouritism, nepotism, ethnic and political consideration and other factors that unseat qualification, experience and performance.

6.3 Problems of participation, coordination and planning 
The principle that should underlie the structure of Local Government is that those most affected by Council decisions must have the capacity to voice their opinion. Local governments often prepare estimates for revenue and expenditure without proper recourse to, and due consultation with, the people for whom the exercise is being carried out to know their needs, their problems and potentials.

Hard-earned and limited resources accrued to and raised by local government are always mismanaged. Priorities are misplaced; projects are done not according to or as demanded by the people but regrettably in tune with the selfish end and aggrandisement of the political leadership in collaboration with the senior bureaucrats at the local government level of administration.

\subsection{Corruption and lack of monitoring and evaluation}

Arguably the bane of development in the Nigerian public service in general and local government in particular, corruption remains a major constraint on the effectiveness of local government service delivery. Too often public funds meant for developmental purposes are mismanaged and cannot be accounted for.

Generally, wide-scale embezzlement by officials of the grassroots has made the needed development of the grassroots a tall dream and has rendered them financially incapable to discharge their constitutionally assigned responsibilities. This can be largely attributed to a noticeable absence of a workable M \& E framework.

\subsection{Lack of autonomy and undue interference by higher political authorities}

The Nigerian Constitution 1999 is rather equivocal on the autonomy and powers of local governments in relation to the state government. Article 7 empowers the state government to enact legislation with regard to "the establishment, structure, composition, finance and functions" of democratically elected local government councils. Also, the Fourth Schedule of the Nigerian Constitution 1999 assigns some roles to local governments in the provision of critical basic services including primary education, health services and the development of agriculture. However, in practice, state governments exercise virtually unlimited jurisdiction in these same arenas. In many cases, the role of local governments is largely relegated to mere participation in the execution of functions. For instance, the Constitution states: "The functions of a local government council shall include participation of such council in the Government of a State as respects the following matters: (a) the provision and maintenance of primary, adult and vocational education; (b) the development of agriculture and natural resources, other than the exploitation of minerals; (c) the provision and maintenance of health services; and (d) such other functions as may be conferred on a local government council by the House of Assembly of the State" Hence, critical basic public services which determine the MDGs status -primary education and health, water and sanitation -are given as responsibility of the state and local governments without clear distinction.

The contradiction regarding the status of local governments is even more pronounced on revenue, spending and fiscal matters. Section 162 (5)-(6) of the Nigerian Constitution 1999 provides for the channeling of local government share of the Federation Account to local government councils. It specifically states that "the amount standing to the credit of local government councils in the Federation Account shall be allocated to the states for the benefit of their local government councils on such terms and in such a manner as may be prescribed by the National Assembly" and that "each state shall maintain a special account to be called State Joint Local Government Account into which shall be paid all allocations to the local government councils of the state from the Federation Account and from the Government of the State". Because of ample discretional powers allowed state governments in control of local governments, different states accord different levels of autonomy/independence to local governments. Hence, in many cases, local governments function mostly as extensions or appendages of state governments.

In practice, there is high degree of external influence and interference in local government affairs by the higher levels of government, particularly the state governments. There have been instances where state governors unconstitutionally dissolve the entire elected council's officers without proper recourse and due process. There is also, in practice, a one-party system, which tends to monopolise political power, and is cautious about delegating real decision-making power

Overall, the local government system has not lived out the intentions and aspirations underlying its creation. This is despite the huge inputs that level of government has received from the centre over the years. This is shown from the astronomic rise in fiscal allocation from a paltry 3 to $5 \%$ in 1976 to $10 \%$ in 1981 to as high as between 20 to $23 \%$ 
presently. This is in addition to $10 \%$ internally generated revenue from the states, together with local government's own internal sources.

In attempting to identify the determinants of successful local governments, Olowu and Smoke (1992) specify:

- Size is not critical for revenue generation.

- The successful cases are all located in regions that are relatively well-developed economically.

- Success is dependent on clear responsibilities and powers, and many of the success cases have powers and responsibilities fairly close to the colonial model.

- Revenues come from indirect taxation on economic activities.

- Most of them have local authority enterprises as an important source of revenue.

Wunsch's (2004) argument is that three major factors facilitate the effective performance of local governments. These factors are resources, authority and a working grassroots-based political process. Greater levels of each of these were expected to be positively associated with improved local government performance, with the latter including internal operations and delivery of services appropriate for local needs.

The lesson for Nigeria is that good governance or local self-governance for that matter, requires both knowledge and will on the one hand and supporting and consistent institutional arrangements on the other hand. Those matters concerning knowledge and institutional arrangements are not independent and additive, but are related to each other. Therefore, good governance at the local level can only be accomplished through institutional arrangements that are radically and consistently polycentric. To try to mix hierarchical ordering processes (as we are currently experiencing in Nigeria) into such a polycentric setting is a recipe for the generation of societal conflict.

i) Lack of clear policy and institutional framework of inter-governmental relations that can ensure that resources allocated to local governments achieve their socio-economic objectives.

ii) The system of local government revenue which makes them heavily dependent for up to $94 \%$ of total revenue on external sources practically exclude the citizens from the budgetary and governance process.

iii) The present mechanisms for ensuring accountability and transparency at the local government leave too much power in the hands of the executive mayor and less in the council, the community and the citizenry.

In order to optimise the contributions of local governments to poverty reduction and sustainable economic development, certain fundamental requirements need to be addressed.

\section{Imperatives for Optimising the Effectiveness of Local Governments in Nigeria}

\subsection{Constitutional and institutional reforms}

As presently constituted, the local governments in Nigeria have muted powers and leverage in the areas of revenue creation, spending autonomy and development functions. Reforms are needed to increase the fiscal and spending autonomy of local governments and minimise the interference and control of state governments. Even though the local government is commonly referred to as the third-tier of government, it is debatable whether it truly qualifies as third-tier of government. This is because the local government do not have the full compliments of a full three-arm government, like federal and state governments. There is therefore need for constitutional reforms to provide unique guarantees for the autonomy and powers of the local government. Alongside, institutional reforms are important to clarify and align local governments' roles and responsibilities in a manner that earns public confidence, intergovernmental credibility and unequivocal accountability.

7.2 Capacity building - institutional and human resources

Several studies have found that the capabilities for fiscal policy, public spending, service delivery and policy development is weakest at the local government level. Similarly, the quality of human resources (skills, competencies and abilities) at the local government level is relatively much lower than at the levels of state and federal governments. Many local governments lack the requisite capacities to develop and implement policies and programmes, to mobilise and attract funding other than revenue from the federation account. It is therefore not surprising that the local governments have not been effective as a level of government. And as a result, there is very low public confidence in the local governments. 
The remedy is systematic capacity building for the local governments. Such a programme should be designed and implemented with external technical assistance and in conjunction with the state and federal governments. The capacity building programme should be two-dimensional. The first is institutional strengthening - with respect to the various organs, departments, units and relationships and operational matters. This should involve training and orientation in policy development, monitoring and evaluation, public participation, public service delivery, social mobilisation and government collaboration with the private sector. The other dimension is human resources upgrading - including training and education of staff to enhance their knowledge, skills and competencies. The working environment should be upgraded to attract higher quality well motivated staff.

\subsection{Empowerment and strengthening of civil society}

Compared to the situation at the state and federal government levels, there is low demand or pressures for public accountability and good governance by civil society at the local level. This is because civil society is very weak at the local levels. The segments of civil society including trade associations, market unions, community associations, faith-based groups, business communities, artisans' associations and students' groups are too fragmented, disarticulate and unenlightened. As a result, there are no collective, coordinated and sustained pressures for good governance at the local government level. There is low level of public awareness and sensitisation of the statutory roles and potentials of local governments in promoting social and economic wellbeing of the local people. It is therefore imperative to have public education, enlightenment and advocacy on the possible and unexploited contributions of local governments to resolving development bottlenecks and providing an enabling environment for social and economic life. In the past, development partners have focused almost exclusively on federal- and statelevel civil society and non-state actors in capacity building. It is time to focus on the local governments because of their great unexploited advantages for local social and economic development.

\subsection{Incentives for good governance at the local levels}

There seems to be a problem of accountability of local governments. The structure of intergovernmental transfers can be fashioned to strengthen incentives for better allocation of public resources. One such measure is the provision of additional funds conditional on improvements in service delivery, ascertained after diligent service delivery assessments. Such conditional grants or transfers are important tools for encouraging and mobilising local authorities for better delivery of public services, more efficient public spending and good governance.

Improved intra-governmental coordination: A sustainable framework for coordination among three levels of government needs to be developed. Here, deployment issues and interference by political parties as well as problems within local governments themselves, where there are often no clear distinctions between councils and Administrations need to be addressed. Furthermore issues of oversight need to be clearly addressed. These functions may need to be entrusted to an independent body and not the State or Federal governments. Furthermore issues of corruption can also be identified here.

\section{Bibliography}

Adamolekun, L. (1991). Decentralization policies: Problems and perspectives. Asian Journal of Public Administration, 13(1), 67-92.

Akindele, S.T. and Olaopa, O.R. (2002). Fiscal federalism and local government finance in Nigeria. International Review of Administrative Sciences, 68(4), 557-577.

Akinsola, H. A. (1993). Community health and social medicine in medical and nursing Practice. Ibadan: 3 AM. Communications.

Anyanwu, J. C. (1999). 'Fiscal relations among the various tiers of government in Nigeria' In Fiscal Federalism and Nigerian's Economic Development. NES Selected Papers Presented at the 1999 Annual Conference Ibadan.

Appadorai, A. (1975). The substance of politics. New Delhi: Oxford University Press.

Beall Jo (2005). Decentralising government and centralising gender in Southern Africa: Lessons from the South African experience. Occasional Paper 8, United Nations Research Institute for Social Development.

Børhaug, K. (1994). Local government and decentralisation in Sub-Saharan Africa: An annotated bibliography. Chr. Michelsen Institute Working Paper. WP 1994: 5. 
Brancati, D. (2005). Decentralization: Fuelling the fire or dampening the flames of ethnic conflict and secessionism. Harvard University Cambridge, Massachusetts.

CBN (2010). Annual report and statement of accounts for the year ended $31^{\text {st }}$ December 2010. Abuja: Central Bank of Nigeria.

Eboh, E. C. and Lemchi, J.I. (2010). Business environment in Nigerian states 2010. Tackling the security challenge. Enugu: African Institute for Applied Economics.

Eboh, E. C. and Agu, C. (2006). Assessing and benchmarking business environment across Nigerian states: the BECANS framework. BECANS Working Paper Series. Enugu: African Institute for Applied Economics.

Eboh, E. C., Amakom, U. and Oduh, M. (2006). Budget and public expenditure across Nigerian states. BECANS Working Paper No. 3. Enugu: African Institute for Applied Economics.

Eboh, E. C. and Igbokwe, E. M. (2006). Economic competitiveness across Nigerian states: The Challenge of Infrastructure and Utilities. BECANS Working Paper No. 2. Enugu: African Institute for Applied Economics.

Ekpo, A. H. (2004). "Intergovernmental fiscal relations: The Nigerian experience". Paper presented at the $10^{\text {th }}$ Anniversary of the Financial and Fiscal Commission of South Africa, Capetown, 10-12 August 2004.

Ekpo, A. H. and Ndebbio, J. (1998). Local government fiscal operations in Nigeria. AERC Research Paper 73. Nairobi: Kenya.

Federal Republic of Nigeria. Constitution of the Federal Republic of Nigeria 1979. Lagos: Federal Government Printer.

Federal Republic of Nigeria. Constitution of the Federal Republic of Nigeria 1999. Lagos: Federal Government Printer.

Heald, D. (1983). as cited by Iyoha F.E. (1999) in Local government and rural development: A bottom-up perspective. Lagos: Sylva Publications Limited.

Herber, B. P. (1979). Modern public finance. Homewood: Richard D. Irwin, Inc.

Imuetinyan, F.O. (2002). Issues in Nigerian government and administration. Benin City: Denvic Publishing Company.

Mawhood, P. (ed.). (1983). Local government in the third world. The experience of tropical Africa. New York, Toronto: John Wiley.

Obadan, M.I. (2002) Poverty reduction in Nigeria: The way forward. CBN Economic \& Financial Review, 39 (4).

Olowu, D. and Smoke, P. (1992). Determinants of success in African local governments: An overview. Public Administration and Development, 12(1), 1-17.

Omamo, W.O. (1995). The commission of inquiry on Local Authorities in Kenya. Nairobi: Government Printer.

Oviasuyi, P.O.; Idada, W. and Isiraojie, L. (2010.) Constraints of local government administration in Nigeria. Journal of Social Sciences, 24 (2), 81-86.

Ransome-Kuti, O., Sorungbe, A.O., Oyegbite, K. and Bamisaye, A. (eds). (1990). Strengthening primary health care at local government level: The Nigerian experience. Ibadan: Academy Press.

Smith, B.C. (1985). Decentralization: The territorial dimension of the state. London: George Allen.

Ukiwo, U. (2006). "Creation of local government areas and ethnic conflicts in Nigeria: The case of Warri, Delta State" a paper presented at the CRISE West Africa Workshop, March 2006, Accra, Ghana.

World Bank. (2002). State and local governance in Nigeria. Sector Report No. 24477. Washington, DC.

World Bank. (1996). Nigeria: Poverty in the midst of plenty: the challenge of growth with inclusion: A World Bank Poverty Assessment. Sector Report No. 14733, Washington, DC.

Wunsch J.S. (2001). Decentralisation, local governance and 'recentralisation' in Africa. Public Administration and Development. 27, 277-288. 
Journal of Economics and Sustainable Development ISSN 2222-1700 (Paper) ISSN 2222-2855 (Online)

Vol.1, No.1, 2010

Table 1: Population, Local Governments and States in Nigeria

\begin{tabular}{|l|l|l|l|}
\hline State & $\begin{array}{l}\text { Area } \\
\text { km })\end{array}$ & Population & $\begin{array}{l}\text { No. } \\
\text { LGAs }\end{array}$ \\
\hline Abia & 4,900 & $2,845,380$ & 17 \\
\hline Adamawa & 38,700 & $3,178,950$ & 21 \\
\hline Akwa Ibom & 6,900 & $3,902,051$ & 31 \\
\hline Anambra & 4,865 & $4,177,828$ & 21 \\
\hline Bauchi & 49,119 & $4,653,066$ & 20 \\
\hline Bayelsa & 9,059 & $1,704,515$ & 8 \\
\hline Benue & 30,800 & $4,253,641$ & 23 \\
\hline Borno & 72,609 & $4,171,104$ & 27 \\
\hline Cross River & 21,787 & $2,892,988$ & 18 \\
\hline Delta & 17,108 & $4,112,445$ & 25 \\
\hline Ebonyi & 6,400 & $2,176,947$ & 13 \\
\hline Edo & 19,187 & $3,233,366$ & 18 \\
\hline Ekiti & 5,435 & $2,398,957$ & 16 \\
\hline Enugu & 7,534 & $3,267,837$ & 17 \\
\hline FCT & 7,607 & $1,406,239$ & 6 \\
\hline Gombe & 17,100 & $2,365,040$ & 11 \\
\hline Imo & 5,288 & $3,927,563$ & 27 \\
\hline NBS, 2010 & & & \\
\hline
\end{tabular}

\begin{tabular}{|l|l|l|l|}
\hline State & $\begin{array}{l}\text { Area } \\
\text { km) }\end{array}$ & Population & $\begin{array}{l}\text { No. } \\
\text { LGAs }\end{array}$ \\
\hline Kano & 20,280 & $9,401,288$ & 44 \\
\hline Katsina & 23,561 & $5,801,584$ & 34 \\
\hline Kebbi & 36,985 & $3,256,541$ & 21 \\
\hline Kogi & 27,747 & $3,314,043$ & 21 \\
\hline Kwara & 35,705 & $2,365,353$ & 16 \\
\hline Lagos & 3,671 & $9,113,605$ & 20 \\
\hline Nasarawa & 28,735 & $1,869,377$ & 13 \\
\hline Niger & 68,925 & $3,954,772$ & 25 \\
\hline Ogun & 16,400 & $3,751,140$ & 20 \\
\hline Ondo & 15,820 & $3,460,877$ & 18 \\
\hline Osun & 9,026 & $3,416,959$ & 30 \\
\hline Oyo & 26,500 & $5,580,894$ & 33 \\
\hline Plateau & 27,147 & $3,206,531$ & 17 \\
\hline Rivers & 10,575 & $5,198,716$ & 23 \\
\hline Sokoto & 27,825 & $3,702,676$ & 23 \\
\hline Taraba & 56,282 & $2,294,800$ & 16 \\
\hline Yobe & 46,609 & $2,321,339$ & 17 \\
\hline & & &
\end{tabular}

NBS, 2010

Table 2: Vertical allocation of Nigerian government revenues since 1981

\begin{tabular}{|l|l|l|l|l|}
\hline \multirow{2}{*}{ Period } & \multicolumn{5}{|c|}{ \% share going to } \\
\cline { 2 - 5 } & $\begin{array}{l}\text { Federal } \\
\text { Government }\end{array}$ & $\begin{array}{l}\text { State } \\
\text { Government }\end{array}$ & $\begin{array}{l}\text { Local } \\
\text { Government }\end{array}$ & $\begin{array}{l}\text { Special } \\
\text { Funds }\end{array}$ \\
\hline$* 1981$ & 55 & 35 & $\mathbf{1 0}$ & - \\
\hline 1989 & 50 & 30 & $\mathbf{1 5}$ & 5 \\
\hline 1993 & 48.5 & 24 & $\mathbf{2 0}$ & 7.5 \\
\hline 1994 & 48.5 & 24 & $\mathbf{2 0}$ & 7.5 \\
\hline $1992-1999$ & 48.5 & 24 & $\mathbf{2 0}$ & 7.5 \\
\hline May 2002 & 56 & 24 & $\mathbf{2 0}$ & - \\
\hline March 2004 till date & $* * 52.68$ & 26.72 & $\mathbf{2 0 . 6 0}$ & - \\
\hline $\begin{array}{l}\text { Current Bill still under consideration at the } \\
\text { National Assembly }\end{array}$ & 53.69 & 31.10 & $\mathbf{1 5 . 2 1}$ & - \\
\hline
\end{tabular}

*Revenue Act of 1981 . 
Journal of Economics and Sustainable Development

Table 3: Summary of Local Governments' Finances

\begin{tabular}{|c|c|c|c|c|c|c|c|c|c|}
\hline & 1993 & 1999 & 2000 & 2004 & 2005 & 2006 & 2007 & 2008 & $2009^{1}$ \\
\hline $\begin{array}{l}\text { CURRENT } \\
\text { REVENUE }\end{array}$ & $19,874.5$ & $60,800.6$ & $151,877.3$ & $468,295.2$ & $597,219.1$ & $674,255.7$ & $832,300.0$ & $1,387,871.3$ & $1,069,365.3$ \\
\hline Federation Account & $18,316.4$ & $43,870.3$ & $118,589.4$ & $375,656.3$ & $493,000.3$ & $550,796.3$ & $568,300.0$ & $722,258.6$ & $529,315.0$ \\
\hline State Allocation & 253.1 & 419.8 & $1,923.1$ & $3,625.7$ & $3,243.9$ & $3,434.8$ & $3,000.0$ & $3,317.4$ & $19,735.7$ \\
\hline Value Added Tax & - & $9,559.8$ & $13,908.7$ & $45,985.2$ & $55,793.6$ & $75,920.0$ & $105,100.0$ & $135,921.3$ & $157,378.6$ \\
\hline Internal Revenue & $1,035.6$ & $4,683.8$ & $7,152.9$ & $22,407.8$ & $24,042.5$ & $23,225.1$ & $21,300.0$ & $22,731.4$ & $26,064.2$ \\
\hline Grants \& Others ${ }^{2}$ & 269.4 & $2,266.9$ & $10,303.2$ & $20,620.2$ & $21,138.8$ & $20,879.5$ & $134,600.0$ & $503,642.6$ & $336,871.7$ \\
\hline $\begin{array}{l}\text { RECURRENT } \\
\text { EXPENDITURE }\end{array}$ & $13,966.5$ & $41,613.9$ & $93,899.9$ & $295,654.7$ & $374,514.6$ & $398,181.2$ & $683,600.0$ & $1,140,100.0$ & $704,610.0$ \\
\hline $\begin{array}{l}\text { Current } \\
\text { Surplus(+)/Deficit(-) }\end{array}$ & $5,908.0$ & $19,186.7$ & $57,977.4$ & $172,640.5$ & $222,704.5$ & $276,074.5$ & $148,700.0$ & $247,771.3$ & $364,755.2$ \\
\hline $\begin{array}{l}\text { CAPITAL } \\
\text { EXPENDITURE }\end{array}$ & $5,508.8$ & $18,827.3$ & $59,964.9$ & $165,395.9$ & $213,463.2$ & $267,656.7$ & $143,800.0$ & $247,800.0$ & $363,003.7$ \\
\hline $\begin{array}{l}\text { TOTAL } \\
\text { EXPENDITURE }\end{array}$ & $19,475.3$ & $60,441.2$ & $153,864.8$ & $461,050.6$ & $587,977.8$ & $665,838.0$ & $827,400.0$ & $1,387,900.0$ & $1,067,613.7$ \\
\hline $\begin{array}{l}\text { Overall } \\
\text { Surplus(+)/Deficit(-) }\end{array}$ & 399.2 & 359.4 & $(1,987.5)$ & $7,244.6$ & $9,241.3$ & $8,417.8$ & $4,900.0$ & $(28.8)$ & $1,751.6$ \\
\hline Financing & $(399.2)$ & $(359.4)$ & $1,987.5$ & $(7,244.6)$ & $(9,241.3)$ & $(8,417.8)$ & $(4,900.0)$ & 28.8 & $(1,751.6)$ \\
\hline (a) Loans & 39.9 & 259.6 & $3,734.6$ & - & - & - & $2,800.0$ & - & $6,076.2$ \\
\hline $\begin{array}{l}\text { (b) Opening Cash } \\
\text { Balance }\end{array}$ & - & $2,499.4$ & $3,356.0$ & $8,714.4$ & $51,707.2$ & $(20,560.1)$ & $37,300.0$ & - & $38,453.4$ \\
\hline (c) Other Funds & $(439.1)$ & $(3,118.4)$ & $(5,103.1)$ & $(15,959.0)$ & $(60,948.5)$ & $12,142.3$ & $(45,000.0)$ & 28.8 & $(46,281.2)$ \\
\hline
\end{tabular}

Source: Central Bank of Nigeria

${ }^{1}$ Provisional figures.

${ }^{2}$ Includes Stabilization Fund, Gen. Ecology and share of Excess Oil Revenue in 2007 \& 2008 and Budget augmentation

Table 4: Revenue source for Local Governments in 2010

\begin{tabular}{|l|r|r|}
\hline Revenue Source & Amount & $\mathbf{\%}$ \\
\hline Federation Account & $529,315.00$ & 49.5 \\
\hline State Allocation & $19,735.70$ & 1.8 \\
\hline Value Added Tax & $157,378.60$ & 14.7 \\
\hline Internal Revenue & $26,064.20$ & 2.5 \\
\hline Grants \& Others & $336,871.70$ & 31.5 \\
\hline Total & $1,069,365.30$ & 100.0 \\
\hline
\end{tabular}

Source: Central Bank of Nigeria 
Figure 1: Progression of Local Government Areas (1976 - 2011)

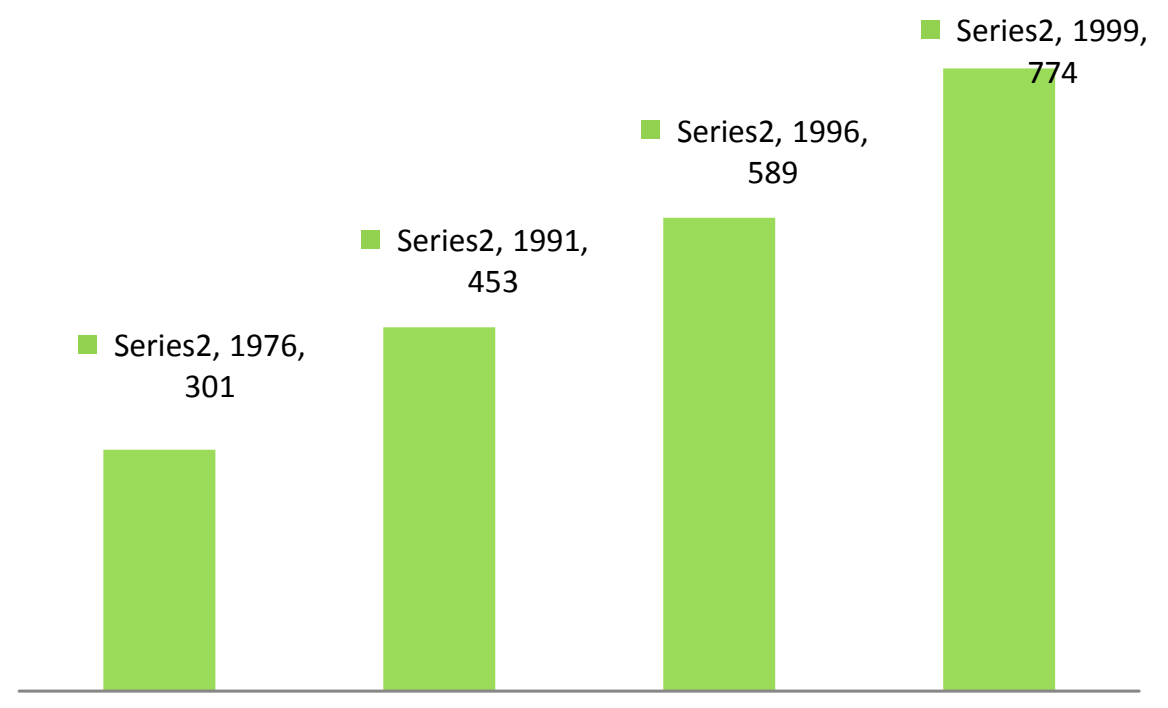

Note: Prior to the 1976 reform, local governments were not uniform.

Figure 2: States and Local Government Areas in Nigeria 


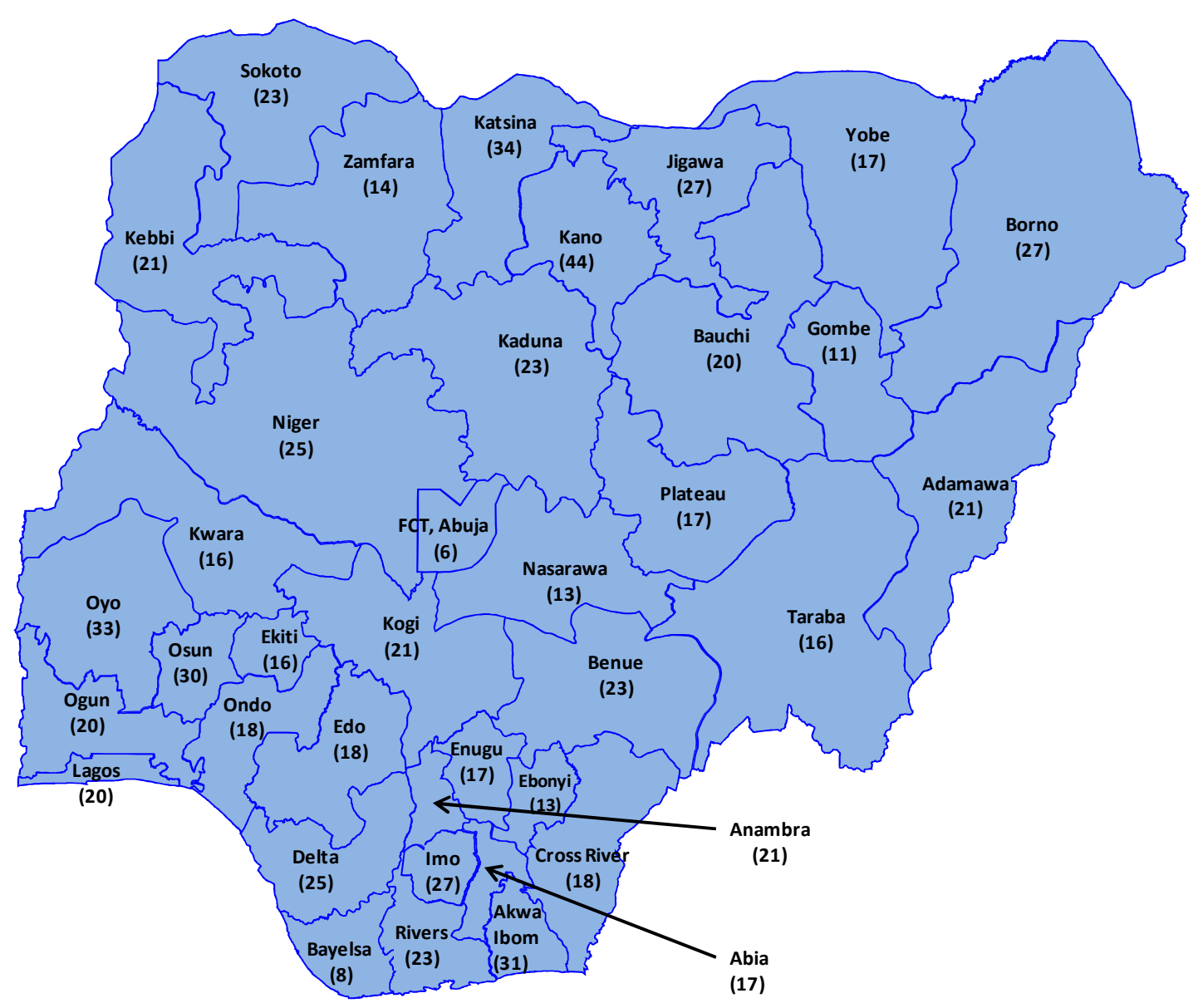

